\title{
Karakterisasi Sifat Optik Lapisan Tipis ZnO doping Al yang di Deposisi diatas Kaca dengan Metode Sol-Gel Teknik Spray-Coating
}

\author{
Sufwan Durri, Heri Sutanto \\ Jurusan Fisika, Fakultas Sains dan Matematika, Universitas Diponegoro \\ Jl. Prof. H. Soedharto, SH., Tembalang, Kota Semarang \\ sdurri@yahoo.co.id dan herisutanto@gmail.com
}

\begin{abstract}
Abstrak - Telah dilakukan sintesis dan deposisi ZnO doping Al mengunakan metode sol-gel teknik spray coating. Lapisan tipis ZnO dengan variasi doping Al diuji menggunakan UV-Vis Spestroscopy. Pengaruh penambahan doping Al pada lapisan tipis ZnO mempengaruhi pergeseran (Shift Blue) pada panjang gelombang $360 \mathrm{~nm}-380 \mathrm{~nm}$, nilai transmitansi lapisan tipis pada sinar tampak dengan rentang 64\%-96\% dan lapisan tipis ZnO tanpa doping nilai transmitansi pada sinar tampak rata-rata lebih dari 90\%. Energi celah pita optik Eg meningkat seiring dengan meningkatnya konsentrasi doping dari 0\%, 2\% dan 4\% dengan nilai Eg 3,102 3,115 eV dan 3,118 eV.
\end{abstract}

Kata kunci: ZnO:Al, Lapisan Tipis, Sol-gel, Spray Coating

\begin{abstract}
Has performed the synthesis and deposition of Al doped ZnO using sol-gel method, spray coating technique. $\mathrm{ZnO}$ thin film with doping variation Al tested using UV - Vis Spestroscopy. Effect of the addition of Al doping in ZnO thin film affects the shift blue at a wavelength of $360 \mathrm{~nm}-380 \mathrm{~nm}$, the transmittance values of thin film in the visible wavelength with a range of $64 \%-96 \%$ and $\mathrm{ZnO}$ pure thin film on visible light transmittance value of the mean average more than $90 \%$. The optical band gap energy increased as the doping concentration was increased from $0 \%$, 2\% and $4 \%$ with Eg value 3,102 eV, 3,115 eV and 3,118 eV.
\end{abstract}

Key words: ZnO:Al, Thin Film, Sol-Gel, Spray Coating

\section{PENDAHULUAN}

Zinc Oxide $(\mathrm{ZnO})$ merupakan material semikonduktor yang penting karena memiliki celah pita lebar, sehingga banyak digunakan untuk beberapa aplikasi seperti transpsrent conductors, solar cell windows, sensor gas, perangkat photovoltaic [1] dan fotokatalis [2]. Material semikonduktor sebagai fotokatalis yang baik untuk degradasi polutan maupun senyawa beracun yakni Zinc Oxide $(\mathrm{ZnO})$, Titania $\left(\mathrm{TiO}_{2}\right)$, Tungtsen Oxide $\left(\mathrm{WO}_{3}\right)$, Zinc Stannate $\left(\mathrm{Zn}_{2} \mathrm{SnO}_{4}\right)$ dll [3]. $\mathrm{ZnO}$ memiliki efisiensi fotokatalis yang tinggi karena dapat menghasilkan $\mathrm{H}_{2} \mathrm{O}_{2}$ yang lebih banyak dibandingkan material semikonduktor $\mathrm{TiO}_{2}[2]$.

Doping merupakan metode yang efektif untuk mengubah sifat fisik (misalnya sifat optik, magnet dan listrik) pada material dan akan memperluas aplikasi/ penerapannya pada material tersebut dari sifat dasarnya [4]. Untuk meningkatkan kemampuan fotokatalis pada material $\mathrm{ZnO}$ perlu merubah sifat fisik dengan memberi doping logam, non-logam atau logam mulia. Material yang digunakan sebagai doping dengan material (Gol. III) seperti Gallium (Ga), Flourine (F), Indium (In), Manganese (Mn) dan Aluminum (Al). Aluminum (Al) sebagai doping menyebabkan seed memiliki morfologi yang meningkatkan luas permukaan lapisan dan berguna untuk efisiensi aktivitas fotokatalis [5].

Lapisan tipis $\mathrm{ZnO}$ dapat disintesis melalui both Solution dan metode berbasis Vakum, yaitu metode berbasis vakum Pulsed Laser Deposition (PLD), Chemical vapour deposition (CVD), Sputtering, Laser ablation, spray pyrolysis [6][7]. Meskipun metode diatas menghasilkan kualitas yang tinggi tetapi teknik ini membutuhkan peralatan yang rumit dan mahal. Alternatifnya, metode deposisi yang bisa digunakan yakni berbasis larutan, seperti Chemical Bath Deposition, sol-gel, electrodeposition, dan hydrothermal [8]. Diantara metode diatas, metode sol-gel merupakan metode yang menarik, karena dapat mengahasilkan lapisan kecil maupun luas yang bagus, sederhana, biaya rendah [4].

Teknik spray-coating merupakan proses dimana material pelapis (feedstock) sebagai partikel individu didorong dengan aliran gas bertekanan ke suatu permukaan (substrat). Partikel tersebut menabrak substrat, menempel, dan membentuk permukaan tipis yang sesuai [9].

Dalam penelitian ini, dilakukan deposisi lapisan tipis $\mathrm{ZnO}$ doping $\mathrm{Al}$ ( $\mathrm{ZnO}: \mathrm{Al})$ di atas substrat kaca dengan menggunakan metode sol-gel teknik spray-coating. Variasi konsentrasi doping Al meliputi 0\%, 2\%, 4\%, 6\%, $8 \%$ dan $10 \%$ dimaksudkan untuk mengetahui pengaruhnya terhadap sifat optik lapisan tipis $\mathrm{ZnO}$ melalui uji karakterisasi Spektofotometer UV-Vis data transmitansinya diolah menggunakan metode Tauc Plot untuk mengetahui celah pita optik.

\section{METODE PENELITIAN/EKSPERIMEN}

$\mathrm{ZnO}$ doping Alumunium ( $\mathrm{ZnO}: \mathrm{Al})$ dengan variasi konsentrasi doping 0\%, 2\%, 4\%, 6\%, 8\%, dan $10 \%$ disintesis dengan metode sol-gel teknik spray-coating pada substrat kaca. Secara umum terdapat tiga tahap, yakni tahap pertama proses pembuatan sol-gel $\mathrm{ZnO}$ tanpa doping dan $\mathrm{ZnO}: \mathrm{Al}$, tahap kedua deposisi lapisan $\mathrm{ZnO}$ dan $\mathrm{ZnO}$ :Al diatas kaca dengan teknik spray-coating dan 
tahap ketiga pengujian sifat optik lapisan tipis $\mathrm{ZnO}$ dan $\mathrm{ZnO}: \mathrm{Al}$.

Pembuatan sol-gel dengan menyiapkan Zinc acetat $\left(\mathrm{Zn}\left(\mathrm{CH}_{3} \mathrm{COO}\right)_{2} .2 \mathrm{H}_{2} \mathrm{O}\right) \quad 0,5 \mathrm{M}$ di masukkan kedalam larutan isopropanol diaduk dengan magnetic stirred pada suhu ruangan selama 15 menit sampai larutan homogen, kemudian teteskan Monoethanolamine (MEA) selama 15 menit atau sampai larutan tidak berwarna atau transparan. Setelah itu, masukkan doping Aluminum nitrat $\left(\mathrm{Al}\left(\mathrm{NO}_{3}\right)_{3} .9 \mathrm{H}_{2} \mathrm{O}\right.$ kemudian diaduk selama 15 menit.

Pelapisan dengan teknik spray-coating, sebelumnya substrat kaca telah dibersihkan dengan aceton, metanol masing-masing selama 10 menit kemudian dibersihkan dengan DI water (deionized water) kemudian diletakkan pada hot plate dengan mengatur suhu $450{ }^{\circ} \mathrm{C}$, spray-coating dilakukan sampai larutan habis terdeposisi. Setelah lapisan terdeposisi pada substrat dianealing selama 1 jam pada tekanan atmosfer.

Pengujian sifat optik lapisan tipis $\mathrm{ZnO}$ dan $\mathrm{ZnO}$ doping Al dilakukan menggunakan UV-Vis Spectroscopy (UVVIS 1240 SA) untuk memperoleh nilai transmitansi pada panjang gelombang $300 \mathrm{~nm}-800 \mathrm{~nm}$.

\section{HASIL DAN PEMBAHASAN}

Pengujian transmitansi optik $\mathrm{T}(\%)$ sebagai fungsi panjang gelombang $\lambda(\mathrm{nm})$ pada gambar (1), seperti yang terlihat pada gambar (1)-(a) adalah spektrum transmitansi optik $\mathrm{ZnO}$ tanpa doping dan gambar (1)-(bf) merupakan lapisan tipis $\mathrm{ZnO}$ yang didoping variasi konsentrasi doping $\mathrm{Al}$. ZnO tanpa doping memiliki transmitansi optik yang tinggi pada daerah sinar tampak rata-rata lebih dari 90\%. Lapisan $\mathrm{ZnO}$ :Al nilai transmitansi pada daerah sinar tampak berada pada range transmitansi $64 \%-96 \%$ yang mengalami penurunan dibanding dengan $\mathrm{ZnO}$ tanpa doping dengan penambahan konsentrasi doping $\mathrm{Al}$ yang semakin besar.

Daerah tepi absorpsi untuk semua lapisan terletak pada range $360 \mathrm{~nm}$ - $380 \mathrm{~nm}$ disebabkan oleh transisi antara pita valensi dan pita konduksi, daerah ini mengalami penurunan karena serapan permulaan dasar [10].

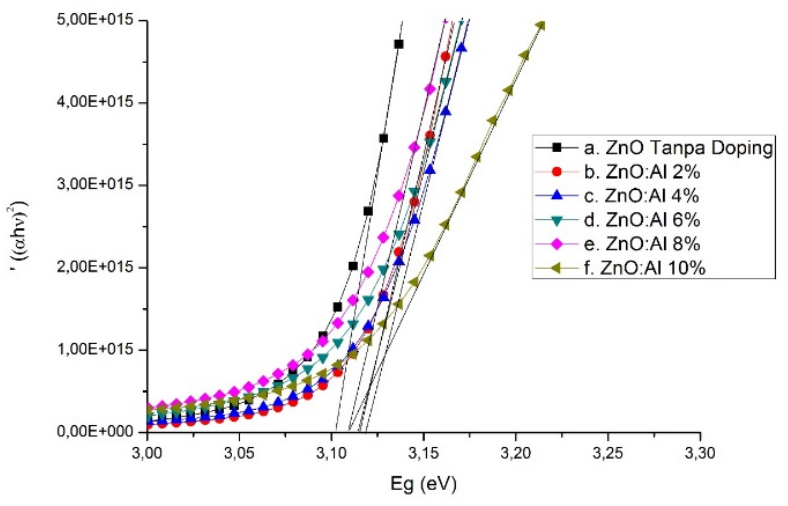

Gambar 1. Spektrum transmitansi lapisan tipis $\mathrm{ZnO}$ sebagai fungsi panjang gelombang variasi doping $\mathrm{Al}$.

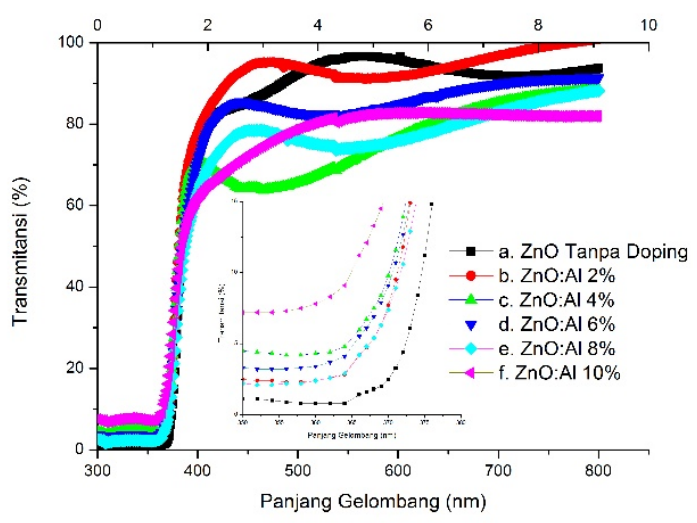

Gambar 2. Penentuan celah pita optik $\mathrm{ZnO}: \mathrm{Al}$ menggunakan metode Tauc Plot.

Pergeseran biru (Blue Shift) seperti yang terlihat pada gambar (1), karena pengaruh tambahan doping $\mathrm{Al}$ mengalami pergeseran ke panjang gelombang yang pendek [11].

Energi celah pita (Eg) pada lapisan tipis $\mathrm{ZnO}$ murni dan $\mathrm{ZnO}$ yang didoping $\mathrm{Al}$ diukur dengan menggunakan spektrum transmitansi dengan mengikuti persamaan:

$$
\begin{aligned}
& \alpha=\ln (1 / \mathrm{T}) \times(1 / \mathrm{e}) \\
& \alpha h v=A\left(E_{g}-h v\right)^{n}
\end{aligned}
$$

dimana $\mathrm{T}$ transmitansi, e ketebalan lapisan tipis, $\alpha$ koefisien absorpsi, h konstanta Planck, $v$ frekuensi gelombang, A konstanta, Eg energi celah pita. Indeks n adalah karakterisasi proses absorpsi dan secara teori masing-masing 2 dan 0,5 untuk tidak langsung dan secara langsung. Nilai $\mathrm{n}$ dapat dideduksi oleh persamaan (1), bahwa semua lapisan tipis yang didoping memiliki celah pita langsung sehingga menggunakan nilai n 0,5 [12]. Selanjutnya, celah pita dihitung dengan menarik garis linier pada ploting $(\alpha h v)^{2}$ dengan energi foton (hv) yang terlihat pada persamaan (2).

Energi celah pita lapisan tipis $\mathrm{ZnO}$ tanpa doping dan ZnO:Al dapat dihitung menggunakan metode Tauc Plot diperoleh nilai Eg seperti terlihat pada gambar (2). Nilai energi celah pita optik (Eg) yang ditampilkan pada tabel (1) pada lapisan tipis $\mathrm{ZnO}$ tanpa doping yakni 3,102 eV, 
Tabel 1. Nilai energi celah pita lapisan tipis $\mathrm{ZnO}$ dan $\mathrm{ZnO}: \mathrm{Al}$

\begin{tabular}{ccc}
\hline No. & Sampel & Energi Celah Pita $(\mathrm{eV})$ \\
\hline 1 & ZnO tanpa doping & 3,102 \\
2 & ZnO: Al 2\% & 3,115 \\
3 & ZnO: Al 4\% & 3,118 \\
4 & ZnO: Al 6\% & 3,115 \\
5 & ZnO: Al 8\% & 3,109 \\
6 & ZnO: Al 10\% & 3,109 \\
\hline
\end{tabular}

dengan penambahan doping $\mathrm{Al}$ pada lapisan $\mathrm{ZnO}$ mempengaruhi meningkatnya nilai Eg dari 3,102 eV; 3,115 eV; 3,118 eV pada konsentrasi $0 \%, 2 \%$ dan $4 \%$. Namun, pada konsentrasi 6\%, 8\%, 10\% mengalami penurunan nilai Eg yakni berturut-turut $3,115 \mathrm{eV} ; 3,109$ $\mathrm{eV}$; dan 3,109. Peristiwa Blue Shift pada doping $\mathrm{Al}$ sebagian besar dianggap berasal dari efek Burstein-Moss, yaitu meningkatnya nilai energi celah pita optik Eg pada lapisan tipis $\mathrm{ZnO}$ seiring dengan meningkatnya konsentrasi doping $\mathrm{Al}$ [7].

\section{KESIMPULAN}

Telah dilakukan pengukuran dan pengujian terhadap sifat optik lapisan $\mathrm{ZnO}$ tanpa doping dan lapisan $\mathrm{ZnO}$ doping Al. Pengaruh penambahan doping Al pada lapisan tipis $\mathrm{ZnO}$ mempengaruhi pergeseran pada panjang gelombang pendek (Blue Shift) yakni pada panjang gelombang $360 \mathrm{~nm}-380 \mathrm{~nm}$, nilai transmitansi lapisan tipis pada sinar tampak dengan rentang 64\%-96\% dan lapisan tipis $\mathrm{ZnO}$ tanpa doping nilai transmitansi pada sinar tampak dengan rata-rata lebih dari 90\%. Hasil pengukuran celah pita energi Eg dengan penambahan doping $\mathrm{Al}$ pada lapisan tipis $\mathrm{ZnO}$ mengalami peningkatan nilai Eg dari lapisan tipis $\mathrm{ZnO}$ tanpa doping 3,102 eV menjadi $(3,115-3,118)$ eV pada konsentrasi $2 \%$ dan $4 \%$.

\section{PUSTAKA}

[1] Bizarro, M., Sanches-Arches A., Garduno-Wilches I., Alonso J.C., Ortiz, A., Synthesis and Characterization of $\mathrm{ZnO}$ and $\mathrm{ZnO}: \mathrm{Al}$ by Spray Pyrolysis with high photocatalytic properties, Catalysis Today, 2011, pp. 129134.

[2] Bizarro, M., High photocatalytic activity of $\mathrm{ZnO}$ and ZnO:Al nanostructured film deposited by spray pyrolysis. Applied Catalysis B: Environmental, 2010, pp. 198-203.

[3] Baruah, S., Pal, S.K., Dutta, J., Nanostructure Zinc Oxide for water treatment, Nanoscience \& NanotechnologyAsia, 2012 Vol.2 No.2, pp. 90-102.

[4] Li, Y., Meng, J., Al-doping effects on structure and optical properties of $\mathrm{ZnO}$ nanostructures, Materials Letters, 2014, pp. 260-262.

[5] Mahadik, M.A., Shinde, S.S., Hunge, Y.M., Mohite, V.S., Khumbhar, S.S., Moholkar, A.V., Rajpure, K.Y., UV Assisted photoelectrocatalytic oxidation of phthalic acid using spray deposited Al doped zinc oxide thin films, 2014, pp. 446-451.
[6] Hafdallah, A., Yanineb, F., Aida, M.S., Attaf, N., In Doped $\mathrm{ZnO}$ thin films, Journal of Alloys and Compounds, 2011, pp. 7267-7270.

[7] Vishwas, M., Rao, K. N., Phani, A.R., Gowda, K.V.A., Chakradhar, R.P.S., Optical, electrical and structural characterization of $\mathrm{ZnO}$ :Al thin film prepared by a low cost sol-gel method, Solid State Communications, 2012, pp. 324-327.

[8] Bu, I.Y.Y., Sol-gel production of alumunium doped zinc oxide using alumunium nitrate, Materials Science in Semiconductor Processing, 2014, pp. 19-25

[9] Surono, A.T., Sutanto, H., Sifat optik Zinc Oxide (ZnO) yang dideposisi diatas substrat kaca Menggunakan Metode Chemical Solution Deposition (CSD) dan Aplikasinya untuk Degradasi Zat Warna Methylene Blue, Youngster Physics Journal, Vol. 2, No. 1, 2014, pp. 7-14.

[10] Benhaoua, B., Rahal, A., Benamache, S., The Structural , Optical and Electrical Properties of nanocrystalline ZnO:Al thin films, Superlattices and Microstructures, 2014, pp. 38-47.

[11] Fang, D., Lin, K., Xue, T., Cui, C., Chen, X., Yao, P., Li, $\mathrm{H}$., Influence of $\mathrm{Al}$ Doping on structural and Optical properties of $\mathrm{Mg}$-Al-co doped $\mathrm{ZnO}$ Thin Films prepared by Sol-Gel Method, Journal of alloy and Compounds, 2014, pp. 346-352.

[12] Lee, M., Huang, M., Legard, D., Lerondel, G., Lin, J., Structure and Characterization of $\mathrm{Sn}, \mathrm{Al}$ co-doped Zinc Oxide Thin Films Prepared by Sol-Gel Dip-Coating Process, Thin Solid Films, 2014, 516-526. 